\title{
Exploring Concept Mapping as a Diagnostic and Predictive Assessment Tool in Pre- Service EFL Teacher Education
}

\author{
Moonyoung Park, Ph.D. ${ }^{1}$ \& Wenqi Xiao ${ }^{2}$ \\ ${ }^{1}$ Department of English Education, Jeju National University, Republic of Korea \\ (D)/0000-0001-9174-9743
}

${ }^{2}$ Faculty of Education, Chinese University of Hong Kong, Hong Kong SAR, China

DOI: https://dx.doi.org/10.46679/978819484836302

Abstract

This study explored (a) pre-service teachers' knowledge structure on teaching English as a foreign language (EFL) reading using concept mapping in a language pedagogy course, (b) the characteristics of concept maps drawn, and (c) the relationship between concept mapping and the course achievement scores. The participants were 14 pre-service teachers majoring in English language education at a university in Hong Kong. The data sources included assessments of concept maps and final exam scores. The overall research findings reveal the educational potential of integrating concept maps as a diagnostic and predictive assessment tool in teacher education programs.

Keywords: Concept map, English as a foreign language, language teacher professional development, assessment in teacher education.

\section{Introduction}

Teachers' pedagogical content knowledge is of the utmost importance for successful classroom instruction and student learning (Pang, 2016; Tsui, 2012). However, little is known about how the 
professional knowledge of pre-service teachers (PSTs) develops during their teacher education. Appropriate assessments for evaluating professional knowledge are required to elucidate the issue. Among several methods of assessing professional knowledge structures (Jonassen et al., 2013), concept maps (CMs) have been shown to be particularly informative and fairly easy to implement in classroom contexts. CMs are graphical instruments used to organize and represent information by establishing meaningful relationships in the form of propositions between concepts (Novak \& Cañas, 2006). A review of the literature (e.g., Koc, 2012; Novak, 1990, Novak \& Canas, 2006) indicates that the use of $\mathrm{CMs}$ has been most prevalent in science education and in primary and secondary levels of education. Therefore, the present study aimed to contribute to developing a research base in the application of CMs within pre-service EFL teacher education by exploring the potential uses and benefits of concept maps. The following section will review prior research on the significance of teacher knowledge and the potential of concept maps.

\section{Literature Review}

\section{Teacher Knowledge as an Outcome of EFL Teacher Education}

Numerous qualities make up an EFL teacher's profession. One of the most critical qualifications of an effective EFL teacher is obtaining pedagogical knowledge as well as knowledge of English as a discipline (Göksel \& Söylemez, 2018). By extension, this brings teacher educators to the issue that pre-service teacher education programs ought to scrutinize the quality of the training provided to PSTs and that PSTs must be held accountable for the extent to which they acquire such professional knowledge from the teacher training (Sheridan, 2016).In this regard, then, it is imperative to monitor and assess PSTs' professional knowledge development throughout the teacher education program (Sandholtz, 2011). 


\section{This is a limited preview of the chapter.}

To read the full-text chapter, get access by purchasing this chapter or consider buying the complete book. If your library has subscription to EBSCOhost, the chapter including other chapters of the book can be accessed through your library.

This chapter is a part of the book, 'Development of Innovative Pedagogical Practices for a Modern Learning Experience' ISBN (paperback): 978-81948483-6-3; ISBN (ebook): 978-81-948483-7-0

Book DOI: https://dx.doi.org/10.46679/9788194848363

Available via CSMFL Bookstore, Amazon, Google Play Books, EBSCOhost \& EBSCO eBooks 
of predictive assessment of lesson planning suggests that a series of successive CMs may be fruitfully used as a formative assessment so that PSTs may visualize the pedagogical reasoning of lesson design.

\section{Disclosure statement}

No potential conflict of interest was reported by the authors.

\section{References}

Ausubel, D. P., Novak, J. D., \& Hanesian, H. (1968). Educational psychology: A cognitive view.

Badusah, J., Kamrozzaman, N. A., Norman, H., Hussin, M., Wahab, J. L. A., Nordin, N., . . . Amat, S. (2017). Cloud-based collaborative mindmapping for lifelong learning analysis in higher education. Paper presented at the 6th International Conference on Literature, Education, Humanities and Social Sciences (LEHSS-17), Istanbul, Turkey.

Blömeke, S., \& Delaney, S. (2012). Assessment of teacher knowledge across countries: A review of the state of research. ZDM, 44(3), 223-247.

Buzan, T. (2006). Mind map: the ultimate thinking tool. HarperCollins Publishers Limited.

Curriculum Development Council in Hong Kong (CDC). (2017). English language education: Key learning area curriculum guide (Primary 1Secondary 6). Hong Kong: HKSAR Government Logistic Department.

Davies, M., Barnett, A., \& van Gelder, T. (2019). Using computer-assisted argument mapping to teach reasoning to students. In J. A. Blair (Ed.), Studies in Critical Thinking (2nd ed., Vol. 8, pp. 131-176). Windsor Studies in Argumentation.

Day, R. R. (1991). Models and the knowledge base of second language teacher education.

Göksel, Ş., \& Söylemez, A. R. (2018). Becoming a professional: Exploring 
EFL pre-service teachers' conceptions of an effective foreign language teacher. Dil ve Dilbilimi Çalışmaları Dergisi, 14(4), 111-135. Gowin, D. B., \& Novak, J. D. (1984). Learning how to learn.Cambridge University.

Grabe, W., \& Stoller, F. L. (2019). Teaching and researching reading, third edition. Taylor and Francis.

Hay, D., Kinchin, I., \& Lygo-Baker, S. (2008). Making learning visible: the role of concept mapping in higher education. Studies in higher education, 33(3), 295-311.

Hosek, V. A. (2018). Locating the critical component in technological pedagogical and content knowledge (tpack): An examination of how graduate students recruit Tpack and critical digital literacy into classroom practices.

Jonassen, D. H., Beissner, K., \& Yacci, M. (2013). Structural knowledge: Techniques for representing, conveying, and acquiring structural knowledge: Routledge.

Kamrozzaman, N. A., Badusah, J., \& Ruzanna, W. M. (2018). Coggle: SWOT analysis in lifelong learning education using online collaborative mind-mapping. International Journal of Academic Research in Business and Social Sciences, 8(12), 2195-2206.

Koc, M. (2012). Pedagogical knowledge representation through concept mapping as a study and collaboration tool in teacher education. Australasian Journal of Educational Technology, 28(4).

Lam, R. (2016). Assessment as learning: Examining a cycle of teaching, learning, and assessment of writing in the portfolio-based classroom. Studies in higher education, 41(11), 1900-1917.

Law, Y. K. (2011). The effects of cooperative learning on enhancing Hong Kong fifth graders' achievement goals, autonomous motivation and reading proficiency. Journal of Research in Reading, 34(4), 402-425.

Lim, H.-W. (2011). Concept maps of Korean EFL student teachers' autobiographical reflections on their professional identity 
formation. Teaching and Teacher Education, 27(6), 969-981.

Lopez, E., Kim, J., Nandagopal, K., Cardin, N., Shavelson, R. J., \& Penn, J. H. (2011). Validating the use of concept-mapping as a diagnostic assessment tool in organic chemistry: implications for teaching. Chemistry Education Research and Practice, 12(2), 133-141.

Markham, K. M., Mintzes, J. J., \& Jones, M. G. (1994). The concept map as a research and evaluation tool: Further evidence of validity. Journal of research in science teaching, 31(1), 91-101.

Novak, J. D. (1990). Concept mapping: A useful tool for science education. Journal of Research in Science Teaching, 27(10), 937-949.

Novak, J. D., \& Cañas, A. J. (2006). The theory underlying concept maps and how to construct them. Florida Institute for Human and Machine Cognition, 1(1), 1-31.

Palpacuer-Lee, C., Hutchison Curtis, J., \& Curran, M. E. (2018). Stories of engagement: Pre-service language teachers negotiate intercultural citizenship in a community-based English language program. Language Teaching Research, 22(5), 590-607.

Pang, M. (2016). Pedagogical reasoning in EFL/ESL teaching: Revisiting the importance of teaching lesson planning in second language teacher education. Tesol Quarterly, 50(1), 246-263.

Pardede, P. (2019). Integrated skills approach in EFL classrooms: A literature review. Paper presented at the English Education Department Collegiate Forum 2015-2018, Cawang, Jakarta.

Sandholtz, J. H. (2011). Preservice teachers' conceptions of effective and ineffective teaching practices. Teacher Education Quarterly, 38(3), 27-47.

Shariatifar, S., Kiany, G., \& Maftoon, P. (2017). High school EFL teachers' professional competencies: Content knowledge and pedagogical content knowledge. Applied Research on English Language, 6(4), 499-522.

Sheridan, L. D. (2016). Examining changes in pre-service teachers' beliefs of pedagogy. 
Shulman, L. (1987). Knowledge and teaching: Foundations of the new reform. Harvard educational review, 57(1), 1-23.

Sümen, Ö. Ö., \& Çalisici, H. (2016). Pre-service teachers' mind maps and opinions on STEM education implemented in an environmental literacy course. Educational Sciences: Theory and Practice, 16(2), 459-476.

Tanriseven, I. (2014). A tool that can be effective in the self-regulated learning of pre-service teachers: The mind map. Australian Journal of Teacher Education, 39(1), 5.

Tseng, J.-J., Chai, C. S., Tan, L., \& Park, M. (2020). A critical review of research on technological pedagogical and content knowledge (TPACK) in language teaching. Computer Assisted Language Learning, 1-24. doi:10.1080/09588221.2020.1868531

Tsui, A. B. M. (2012). The dialectics of theory and practice in teacher knowledge development. In J.Hüttner, B.Mehlmauer-Larcher, S. Reichl\& B.Schiftner (Eds.), Theory and practice in EFL teacher education: Bridging the gap (pp. 16-37). Multilingual Matters.

Turner, J. L. (2014). Using statistics in small-scale language education research: Focus on non-parametric data: Routledge.

Voithofer, R., \& Nelson, M. J. (2020). Teacher Educator Technology Integration Preparation Practices Around TPACK in the United States. Journal of teacher education, 0022487120949842.

\section{About Authors}

Moonyoung Park, PhD, is an Assistant Professor in the Department of English Education in the College of Education at Jeju National University, Korea. His research has focused on language teacher education, aviation English assessment, computer-assisted language learning, and language test development and validation. He is the Vice President of the Asia-Pacific Association for Computer-Assisted Language Learning APACALL: www.apacall.org. 
Wenqi Xiao is a Doctoral student in the Department of Curriculum and Instruction in the Faculty of Education at the Chinese University of Hong Kong, Hong Kong SAR. Her research has focused on computerassisted language learning and peer assessment in the second language speaking. 
